\section{UK government claims half of MRC's patent profits}

The UK Medical Research Council (MRC) is being forced to hand over half of the money it has earned from exploiting its intellectual property.

The MRC's $£ 200$-million (US\$400million) 'commercial fund' consists of the profits from discoveries such as monoclonal antibody technology. In the past, the MRC had been allowed to keep the money and use it to build medical research facilities.

But on 14 December MRC officials announced that $£ 92$ million would be given over to the government's consolidated fund, which is used by the Treasury to fund general programmes. Martin Rees, the president of the Royal Society, Britain's main independent scientific body, called the move a "breach of faith" with scientists.

"In fairness, a lot of the money is being retained for science," says Leszek Borysiewicz, the MRC's chief executive. The MRC will also be able to keep future intellectual-property earnings, as long as they are forecast correctly. But he adds that the decision by the Treasury is "worthy of debate".

\section{Pasteur Institute fined over patent dispute}

A French court has slammed the ethical behaviour of Paris's prestigious Pasteur Institute and ordered it to pay $€ 150,000$ (US\$215,000) in damages to Rupert Mutzel, a biologist at the Free University of Berlin, for denigrating his scientific reputation.

In the 1990s, Mutzel and Philippe

Marlière - then a researcher at the Pasteur Institute - patented a microbial technique for selecting accelerated proliferation of living cells in suspension. An exclusive licence was agreed for Marlière to utilize the patent. But in 2003, the institute revoked the licence without asking Mutzel, and negotiated a new one with another company, Eco-Solution.

The court ruling, which became public on 12 December, says that the institute tried to mislead the court by concocting "totally imaginary" evidence against Mutzel. The court also criticized the institute's ethics committee for throwing doubts on Mutzel's integrity and for saying that it "regretted" that he had "provoked a legal conflict". The court told the committee that it was normal for Mutzel to take legal action to defend his rights.

The Pasteur Institute says the current management does not dispute Mutzel's status but adds that it will appeal against the size of the fine. A separate case against the institute by Marlière is pending.

\section{Congress tightens rules on fuel standards for cars}

Democrats in the US Congress have struck a deal on legislation to increase the fuel efficiency standards for motor vehicles - the first such increase in more than three decades.

The legislation would increase the standards by roughly $40 \%$, to 15 kilometres per litre, by 2020 , while instituting a series of energy-efficiency requirements for appliances and federal buildings.

The bill would also mandate the use of 136 billion litres of biofuels annually by 2022 , compared with roughly 25 billion litres this year. Of the total, 80 billion litres must come from advanced biofuels such as cellulosic ethanol and meet certain requirements for greenhouse-gas emissions.

Facing opposition from Republicans and the White House, Democrats had to jettison a federal mandate for the production of electricity from renewable sources and a tax package shifting energy subsidies from

\title{
Springtime outburst on Mars
}

Channels carved by vaporizing carbon dioxide splay across the south polar region of Mars in this image taken by the Mars Reconnaissance Orbiter.

Last week, at the American Geophysical Union meeting in San Francisco, project scientists reported that the channels probably form as the warmth of spring causes carbon dioxide in the soil to vaporize, then flow upwards

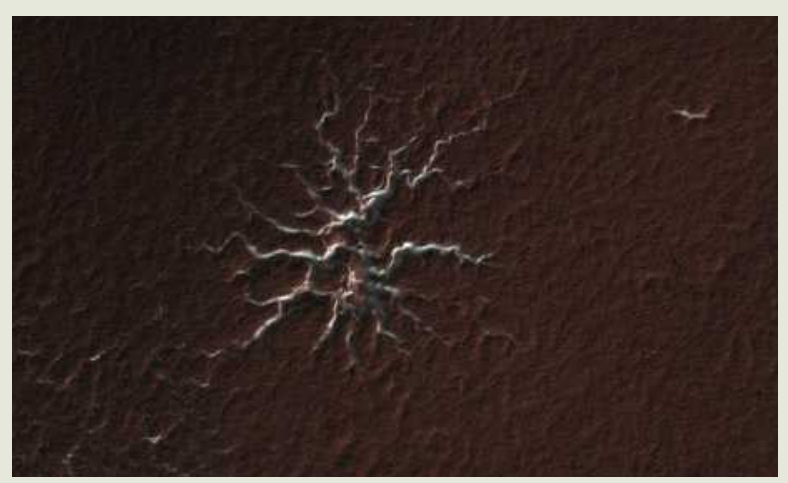

and burst out like geysers. Some of the gas then rapidly freezes and falls back to the ground in a brilliant white frost pattern. The strange features, radiating out from the top of small hills, were snapped during the martian spring in March.

fossil fuels to renewable energies.

The Senate passed the bill on 13 December, and the House of Representatives was moving towards passage as Nature went to press this week. The president is expected to sign the bill.

\section{CERN names its next head as collider is set to go online}

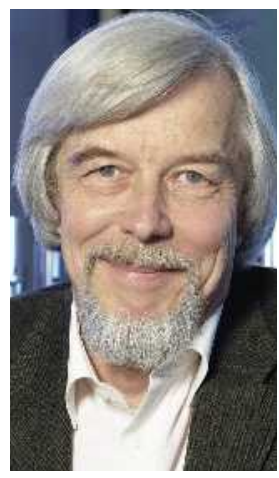

Rolf-Dieter Heuer.
The next directorgeneral of CERN, Europe's primary high-energy physics laboratory near Geneva, Switzerland, will be Rolf-Dieter Heuer, who will take the reins in January 2009.

Heuer, whose appointment was announced on 14 December by the

CERN Council, is currently a research director at Germany's DESY laboratory in Hamburg. He will replace Robert Aymar, who has run the laboratory since 2004.

Heuer says his top priority will be to ensure a smooth transition from the construction of the Large Hadron Collider, a SFr10-billion (US\$8.7-billion) particle accelerator to its operation after it is completed. Heuer also says that he will seek to improve cooperation with particlephysics laboratories in the United States and Japan.

He adds that he will "keep options open” for CERN's future, including its participation in the International Linear Collider, a proposed next generation of particle accelerator.

\section{Science appoints Bruce Alberts as editor-in-chief}

Biochemist Bruce Alberts, an American known best for his seminal textbook Molecular Biology of the Cell and an advocate of international scientific cooperation, will take over as editor-in-chief of the journal Science beginning in March.

Alberts served as president of the US National Academy of Sciences from 1993 to 2005, and is currently co-chair of the InterAcademy Council, an Amsterdambased international collaboration of science academies from 15 countries. $\mathrm{He}$ is based at the University of California, San Francisco.

Alberts replaces Donald Kennedy, a biologist and former president of Stanford University in California, who has edited the journal since 2000 . 